\author{
Arne Löfstedt \\ Göteborgs universitet
}

DOI: http://dx.doi.org/10.5617/adno.6283

\title{
Det första nationella provet i samhällskunskap - en studie i bedömarsamstämmighet
}

\section{Sammanfattning}

Skolämnet samhällskunskap som eget ämne existerar $i$ princip enbart $i$ de nordiska länderna. I många andra länder delar flera skolämnen på ämnesinnehållet, till exempel geografi och civics. Ämnesinnehållet är stort och genomgår ständig förändring. År 2013 genomfördes de första nationella proven i samhällskunskap i Sverige för årskurs 9. Med tanke på ämnets karaktär kan det vara speciellt viktigt att undersöka om dessa prov är "rättvisa."

Avsikten med denna studie är att undersöka en aspekt av denna "rättvisa", nämligen interbedömarstabilitet, $d v$ s om samma elevsvar ger upphov till samma bedömning oavsett bedömare. Skolverket i Sverige genomförde 2009 en större studie av de ämnen som då genomförde nationella prov och föreliggande studie försöker dels efterlikna och dels bygga ut upplägget från Skolverket. Studien genomfördes på de första nationella proven i samhällskunskap 2013. Genom att pröva olika reliabilitetsmått inom kategorierna "consensus estimates", och "consistency estimates" analyseras resultaten, bland annat diskuteras måttet intraclass correlation. Syftet är också, då detta var de första proven, att skapa en ram för återkommande studier av Interbedömarreliabilitet. Upplägget med en större mängd lärare som genomför totalt tre bedömningar av de utvalda hela proven försöker också efterlikna bedömningssituationen ute på skolorna såtillvida att det var relativt många lärare med i studien, och de kom från olika skolor spridda över Sverige. Genom detta testas också bedömningsanvisningarnas stabilitet. Själva genomförandet var omfattande och tog två hela dagar. Resultaten pekar på en god överensstämmelse för provbetyget, det sammanfattande omdöme eleverna får. Studien avses att återupprepas under kommande år.

Nyckelord: Samhällskunskap, nationella prov, interbedömarreliabilitet, intraclass correlation 


\title{
The first national test in samhällskunskap - a study of interrater reliability
}

\begin{abstract}
The Swedish school subject Samhällskunskap (Societal knowledge) exists basically only in the Nordic countries. In other countries a number of different subjects, such as geography and civics, share the content. The content of the subject is constantly changing, depending on how society is changing. The first national tests in Samhällskunskap for all Swedish ninth graders took place in 2013. A large part of the test contains constructed responses.

Given the characteristics of the subject we consider it especially important to investigate whether these tests are "fair" or not. The intent of this study is to investigate one aspect of "fairness", interrater reliability, meaning the degree to which the same student responses are scored equally by different raters. In 2009, the National Agency of Education in Sweden conducted a large study of the subjects Swedish, English and Mathematics. Our study aims to mimic and further develop the design of the study from 2009. Our study was carried out on the first national tests in 2013. The results were analyzed by exploring different reliability measures within the categories consensus estimates, and consistency estimates.

As the 2013 tests were the first tests of its kind in Sweden the purpose was also to create a framework for regular studies of interrater reliability. The rater design with a relatively large number of teachers from all over the country, each assessing a total of three complete student test responses aimed at mimicking the way the tests are assessed in schools. This also allowed us to study the stability of our assessment rubrics. The study itself was extensive and took two days to perform. The results indicate a large compliance when it comes to the final grade of the test. The study is meant to be repeated in the coming years.
\end{abstract}

Keywords: Social science, civics, national testing, interrater reliability, intraclass correlation

\section{Inledning}

Universiteten som utvecklar de nationella proven i Sverige på Skolverkets uppdrag ska under 2017-2019 ta fram helt nya ramverk för proven som styr verksamheten. I juni 2017 antogs ett centralt ramverk för alla ämnesprov av Skolverket (Skolverket 2017). En viktig del i dessa är att regelbundet genomföra större interbedömarreliabilitetsstudier. 
Huvudsyftet med studien är att pröva om ett nationellt prov med så många relativt öppna uppgifter och med så analytiskt inriktade bedömningsanvisningar kan anses vara stabilt vad gäller interbedömarreliabilitet. Tidigare studier i Sverige finns på andra ämnen men inte samhällskunskap. Ett kompletterande syfte är att pröva måttet intra-class correlation, då detta inte finns med i tidigare studier. Proven i SO introducerades först 2013, och det kan vara en anledning till detta.

Den första större gemensamma interbedömarstudien av nationella prov i Sverige genomförde Skolverket 2009, där de nationella proven inom matematik, engelska och svenska testades (Skolverket 2009, Erickson 2009, PRIM-gruppen 2009, Östlund-Stjärnegård 2009). Under våren 2013 genomfördes de första nationella proven i samhällskunskap i åk 6 och åk 9 för första gången. Under hösten 2015 genomförde provgruppen i samhällskunskap större interbedömarstudier av proven i samhällskunskap 2013 för årskurs 6 och 9, bland annat för att testa jämförbarheten med Skolverkets större undersökning 2009. Denna rapport bygger på den studien.

\section{Bakgrund}

Samhällskunskap har funnits som enskilt ämne i grundskolan i Sverige sedan 1962. Det är egentligen bara i de nordiska länderna som samhällskunskap - eller ett ämne med liknande inriktning - finns som eget, fristående ämne.

Det finns i Sverige, Norge eller Danmark inga publicerade rapporter om interbedömarreliabilitet inom nationella prov i samfundsfag/samhällskunskap. Danmark och Norge har för närvarande inga obligatoriska nationella prov i samhällskunskap. Därför är det också så viktigt att studier av nationella prov i samhällskunskap görs.

Huvudsyftet med denna rapport är en jämförelse av det aggregerade resultatet, provbetyget, inte enskilda uppgifter.

\section{Ämnesprovet 2013}

Under sitt sista år i grundskolan, årskurs 9, genomför eleverna i Sverige ett antal obligatoriska nationella prov: i svenska, matematik, engelska, No (naturorienterande ämnen) och SO (samhällsorienterande ämnen). Dessa fem prov innehåller också flera delprov. Inom No gör eleverna ett av proven i fysik, kemi eller biologi. Statistiska Centralbyrån avgör slumpmässigt vilka skolor som ska göra proven och i vilket ämne de ska göras. På samma sätt gör eleverna ett av proven inom SO - i geografi, historia, religionskunskap eller samhällskunskap. Varje årskull består av cirka 100.000 elever, vilket innebär att cirka 25.000 elever gör provet i samhällskunskap varje år. Proven är obligatoriska, och innehållet, dvs. de enskilda frågorna, är sekretessbelagda i fem år. Proven görs analogt. Proven bedöms av lärarna själva, ingen central bedömning görs. Enkäten till provet i samhällskunskap (Göteborgs universitet, 2013) har visat att en stor del av proven sambedömts, kanske eftersom detta var 
det första nationella provet i samhällskunskap. Proven introducerades i samband med genomförandet av en ny läroplan, Lgr11.

\section{Ämnesprovets uppbyggnad}

Nationella provet i samhällskunskap för åk 92013 bestod av två delprov. Dessa delprov skiljer sig inte principiellt åt. I flera andra nationella prov, t.ex. i svenska och engelska sker uppdelningen i delprov efter olika så kallade förmågor, t.ex. muntlig eller skriftlig förmåga, som då prövas i olika delprov. I samhällskunskap är delproven lika varandra, uppdelningen är enbart gjord av tidsskäl; provet görs under två dagar med 2 x 2 timmar per dag. Proven inom SO omfattar 22-30 uppgifter (antalet uppgifter har minskat från 2013 tills idag, 2018), både med strukturerade svarsalternativ och öppna svarsalternativ.

Denna studie vill undersöka graden av samstämmighet på provbetygsnivå. I provet finns både strukturerade och öppna uppgifter. I slutet av denna studie kommenteras de enbart öppna uppgifterna.

Provet i samhällskunskap 2013 bestod av 30 uppgifter $^{1}$. 11 av dessa är att betrakta som öppna frågor där eleverna behöver resonera relativt utförligt. Här följer fem exempel på de öppna uppgifterna ur provet 2013:

- I Sverige betalar vi skatt till kommuner, landsting/regioner och staten. Privatpersoner betalar bland annat skatt på inkomst och moms på köpta varor och tjänster. Företag betalar bland annat moms och arbetsgivaravgifter.

Varför betalar vi skatt? Resonera!

- I Sverige fick vi allmän rösträtt 1921, då var rösträttsåldern 21 år. Den ändrades så småningom till 18 år. Under senare år har röster höjts för en ytterligare sänkning av rösträttsåldern till 16 år, men det har inte genomförts.

Varför är rösträttsåldern 18 år? Resonera!

- På många ställen i världen pågår konflikter inom och mellan länder.

På vilka sätt kan konflikter i världen påverka andra länder, exempelvis Sverige? Resonera!

Du kan använda dessa eller andra begrepp som du väljer själv:

ekonomi flykting handel hot

- Det finns olika villkor som krävs för att ett land skall kallas demokratiskt, ett av dem är allmän och lika rösträtt.

\footnotetext{
1 Ämnesprovet som helhet kan laddas ner från provinstitutionens hemsida:
} ips.gu.se/forskning/forskningsprojekt/nationella-prov-samhallskunskap/ 
Vilka andra villkor bör ett land uppfylla för att kallas demokratiskt? Resonera utförligt!

- På vilka sätt kan det vara ett samhällsproblem att människor diskrimineras? Resonera och använd gärna exempel!

Uppgifternas omfattning går inte att jämföra med uppsatsskrivning i de nationella proven i svenska eller engelska men kan ändå anses vara relativt öppna. En fingervisning om att så är fallet, är att den öppna skrivuppgiften i engelska (Erickson, 2009) genererar ett snitt på 400-430 ord per godkänd "uppsats". Vid ett detaljstudium av två öppna uppgifter framkommer att elever, som erhållit provbetyg A, skrivit i genomsnitt ca. 220 ord per uppgift.

Bedömningsanvisningar för de öppna uppgifterna i samhällskunskap är analytiskt inriktade, dvs. eleverna skall uppfylla ett antal kriterier för att få olika resultat på de olika uppgifterna.

I arbetet med att ta fram uppgifter och bedömningsanvisningar genomförs prövningar av uppgifter på elever som går i årskurs 9. Resultaten av prövningarna analyseras noga. Cirka 3500 elever har medverkat i utprövningar för att få fram uppgifter till provet 2013. Uppgifterna i provet i samhällskunskap är ofta relativt direkta utan någon längre inledning. De genomförda utprövningarna har givit vid handen, att korta inledningstexter fungerar bäst. Förutom öppna uppgifter innehåller provet ett antal uppgifter med strukturerade svarsalternativ, t.ex. matchning, multiple-choice, tabellanalyser med strukturerade svar osv.

Provet som genomfördes 2013 har god reliabilitet som helhet, med Cronbachs alpha på 0.92 .

Det som avses att mätas i ett prov är provets construct ${ }^{2}$. För vår del utgörs detta construct av samhällskunskapsämnets kunskapskrav, såsom det är angivet i läroplanens kursplan för ämnet. Kunskapskraven kan också delas i sex ur innehållssynvinkel relativt olika delar, i studien kallade delar av kunskapskraven (förkortat delkunskapskrav, dkk). I bilaga 1 finns dessa redovisade. För att uppnå god reliabilitet på individnivå bör man pröva en viss mängd uppgifter kring samma område. Av den anledningen har inte alla dkk testats samtidigt utan i provet 2013 prövades tre av sex dkk, vilka också finns redovisade i bilaga 1 .

\footnotetext{
2 Vid en enkel översättningssökning på nätet får man som förslag på construct t.ex. "hypotetisk konstruktion” som i detta sammanhang torde väl svara mot ovanstående. Även "tankeskapelse” är beskrivande. Ordet construct har nu blivit så etablerat att man också får det "svenska” ordet "konstrukt (akademiskt begrepp)". Wikipedia anger "a hypothetical construct is an explanatory variable which is not directly observable".
} 


\section{Metod}

Nedan redovisas tre delar: val av korrelationsmätningar, val av bedömargrupp och urval av elevprov.

\section{Val av korrelationsmätningar}

Interbedömarreliabilitet kan prövas på olika sätt. Stemler (2004) och Stemler och Tsai (2008) anger tre olika kategorier för att utvärdera interbedömarreliabilitet: consensus estimates, consistency estimates och measurement estimates. I den första prövas i vilken mån bedömare kommer fram till exakt samma resultat. Detta brukar anges i varianter av procentuell överensstämmelse eller med mått som Cohens kappa eller Intra Class Correlation m.m. I Skolverkets undersökning 2009 används olika former av procentuell överensstämmelse. Inom consistency estimates prövas hur konsistenta (konsekventa) bedömarna är i sin bedömning, bl.a. om de rangordnar en uppsättning svar på lika sätt. Här används olika korrelationsmått, men i interbedömarsammanhang används oftast Spearmans rangkoefficient (Spearmans rho), då den tillämpar en ordinalskala. Detta innebär att man kan rangordna elevsvar, men att det inte är exakta intervall - som i en intervallskala - mellan de olika bedömningsmåtten. Provbetyget i samhällskunskapsprovet anges i skalan F, E, D, C, B och A där F är inte godkänt resultat och A är högst. Skillnaden mellan ett C och ett B är inte matematiskt exakt lika stort som skillnaden mellan ett $\mathrm{E}$ och ett $\mathrm{D}$. Vid intervallskalor används istället oftast Pearsons $r$ som korrelationskoefficient. Då denna studie försöker följa upplägget i Skolverkets studie (Skolverket, 2009) av de nationella proven, har de mått på korrelation tillämpats som beskrivs där, men utvidgats med Intra Class Correlation (ICC). Genom föreliggande rapport kan nyttan av att ha ytterligare ett mått som ICC visas. Vid beskrivningen av resultaten har i denna studie de två förstnämnda kategorierna så långt möjligt följts.

\section{Interbedömarreliabilitet - consensus estimates. Procentuella mått och Intra Class Correlation}

Denna studie avser att undersöka samtliga uppgifter i ett visst prov och vårt intresse är jämförelse av provbetyg, alltså den sammanfattning av elevens prestation som olika bedömare gör. Ett mått på överensstämmelse ur consensusaspekt är procentuella jämförelser.

Utöver procentuella jämförelser och jämförelser av spridning kan man också inom consencus estimates titta på korrelationsmått av typen Cohens kappa m.fl. Det finns dock en diskussion om Cohens kappa och tillförlitlighet (Gwet, 2002a; Gwett, 2002b; Uebersax, 1987; Uebersax, 2015). Idag används också måttet Intra Class Correleation (ICC). Måttet är intressant för att jämföra bedömningar av svårbedömda material, vilket märks då måttet ofta tillämpas i olika 
bedömningssituationer inom t.ex. psykologi och medicin (se Friedman L et al, 2008; Friedman, 2005; McGraw \& Wong, 1996).

ICC som mått kan användas vid flera olika designer. I litteraturen hänvisas oftast till den indelning som Shrout och Fleish (1979) gjorde. I den statistiska programvaran SPSS används dock en annan nomenklatur som kommer från McGraw and Wong (1996). De olika varianterna av ICC brukar betecknas med ICC $(X, Y)$ där $Y$ hänvisar till graden av slumpmässighet när det gäller bedömarna (1=fullständig slump, $2=$ slumpmässigt val ur en viss mängd bedömare, $3=$ enbart vissa bedömare). $Y$ anger slummässighet när det gäller de bedömda, i studiens fall eleverna, där 1=slumpmässiga, medan andra varianter (benämnda n) oftare är intresserade av medeltal av överensstämmelser. En av de vanligaste varianterna är $\operatorname{ICC}(2,1)$, dvs slumpmässiga bedömare dragna ur ett visst antal, och slumpmässiga dragningar av elevsvar. Det är denna variant som är av intresse här. Variant ICC $(3,1)$ kallas ofta ICC(Consistency), där man är mer intresserade av bedömarna i sig, medan $\operatorname{ICC}(2,1)$ kallas ICC(Agreement), som står för graden av överensstämmelse.

Varianterna av ICC ger något olika koefficienter men ofta ges denna underliggande kategorisering av de korrelationer man fått (Bartko, 1976, Friedman, 2005; Landis och Koch; 1977; McGraw \& Wong, 1996):

Almost Perfect 0.81-1.00

Substantial 0.61-0.80

Moderate 0.41-0.60

Fair $0.21-0.40$

Slight $0.00-0.20$

Poor $<0.00$

\section{Interbedömarreliabilitet - consistency estimates}

I den andra kategorin av bedömaröverenstämmelse undersöks om bedömarna är ense om rangordningen av provsvaren. Eftersom detta är en ordinalskala använder man ofta Spearmans rangkoefficient. På samma sätt som i Skolverkets undersökning från 2009 finns här tre korrelationer mellan de ursprungliga lärarna och våra två ombedömargrupper, organiserade i tre olika uppställningar (se nästa kapitel). Det vanliga är att man anger ett spann, den lägsta och den högsta korrelationen. Spannet bör således både vara litet och siffran givetvis hög, i bästa fall $>0.90$.

Man kan tala om den första kategorin som absolut bedömaröverensstämmelse och den andra som relativ överensstämmelse (Sjöberg, 2015).

\section{Val av ombedömargrupp}

För att utröna hur väl och exakt bedömningsanvisningarna hjälper lärarnaatt bedöma ett visst prov på samma sätt, skulle urvalet av 100 hela prov behöva 
bedömas av 2 x 100 andra bedömare. Nu låter sig en sådan prövning med 2 x 100 nya bedömare inte enkelt göras. I denna studie har i stället 16 verksammalärare genomfört de 2x100 bedömarnas arbete.

Tre korrelationer kommer således att kunna undersökas: a) mellan resultaten av den ursprungliga lärargruppens bedömningar och ombedömargruppens resultat i omgång 1 ; b) mellan ombedömargruppens resultat i omgång 1 och samma grupps resultat i omgång 2; c) mellan den ursprunglig lärargruppens resultat och ombedömargruppens resultat i omgång 2. I tabellerna kallas dessa grupper Lärargrupp, Bed1 respektive Bed2.

Med detta sätt att organisera bedömningen läggs fokus inte på hur en enskild bedömare konsekvent bedömer, utan i stället på den totala samstämmigheten. Man kan säga att intra-bedömningen blir irrelevant, samtidigt som det blir svårare att nå hög korrelation i de metoder som mäter consistency estimates.

Först fördelades de 16 lärarna som utgjorde ombedömargruppen slumpmässigt över de 100 utvalda hela elevproven och sedan slumpmässigt en gång till för att få en tredje bedömning av materialet. Slumpmässigheten hade dock ett undantag; de 16 bedömde aldrig samma prov två gånger. Varje helt prov bedömdes således tre gångar av tre oberoende bedömare, varav den första bedömningen gjordes vid tillfället då provet gavs. På detta sätt minskas intrabedömareffekter. Detta gjordes för att efterlikna en vanlig bedömningssituationen på skolorna, dvs. att många lärarebedömer material enskilt. Detta upplägg har fått beteckningen "nästlat". Andra studier av interbedömarreliabilitet använder mycket få ombedömare, ibland enbart några från provutvecklingsgruppen.

\section{Ombedömargruppen}

på De 16 lärarna i ombedömargruppen kom från 16 olika skolor i helt olika delar av Sverige. Skolorna var olika till storlek och skiljde sig också vad gäller elevernas socioekonomiska situation. Av de 16 var 6 män och 10 kvinnor, och de hade olika lång undervisningserfarenhet. Huvuddelen av gruppen hade inte medverkat i framtagningen av materialet. Fyra lärare i gruppen arbetade dock deltid i provgruppen (en hade $40 \%$ och tre hade $20 \%$ i projektet). Övrig tid arbetade de som lärare i grundskolan. Övriga bedömare var lärare som anmält intresse genom våra enkäter, slumpats fram eller deltagit i utprövningar (utan bedömningsinslag). Tre hade genomfört provet på våren, medan resterande nio aldrig sett vare sig frågorna eller bedömningsanvisningarna. Urvalet av lärare är således inte slumpmässigt, men de flesta i gruppen har aldrig arbetat med dessa frågor ur detta perspektiv.

Varje ombedömare bedömde 12-14 hela prov enskilt, ingen sambedömning förekom. De fick inte reda på den fördelning av provbetyg som fanns i grundmaterialet, och eftersom proven var slumpmässigt fördelade, kunde en bedömares material bestå av prov med vilka betyg som helst. Varje ombedömare genomförde sedan bedömningen av proven som tillhörde omgång ett och två, i 
tabellerna kallade Bed1 och Bed2, vid samma tillfälle. De visste själva inte vilket som tillhörde vilken omgång. Detta är också viktigt, så att man inte får påverkan av att alla ombedömare har sett bedömningsanvisningarna omgång 2, men inte i omgång 1 . Ombedömningen genomfördes under knappt två dagar.

\section{Urval av elevhäften}

Efter genomförandet av provet 2013 skickade lärare in kopierade fullständiga elevhäften för elever födda den 15:e i varje månad. Till Samhällskunskap åk 9 skickades 512 genomförda och bedömda elevhäften in. 223 skolor från 123 kommuner var representerade.

Provbetygsfördelning av det inskickade urvalet jämfört med SCBs totalsiffror från nov -13 framgår av Tabell 1:

Tabell 1 Jämförelse av provbetyg mellan inskickade elevhäften och riket (\%)

Provbetyg Inskickade Riket
\begin{tabular}{|l|l|l|}
\hline F & 2,7 & 1,9 \\
\hline E & 11,3 & 14,6 \\
\hline D & 35,7 & 34,1 \\
\hline C & 29,1 & 29,1 \\
\hline B & 15,2 & 14,7 \\
\hline A & 5,9 & 5,6 \\
\hline
\end{tabular}

Av de inskickade proven slumpades 109 ut med jämn provbetygsfördelning, 20 stycken av varje provbetyg E-A och 9 st. $\mathrm{F}^{3}$. Vid något tillfälle kom samma skola med, och då togs det närmast följande provet. Fördelning pojkar/flickor var helt jämn.

Att få likhet med utfallet av 2013 års provbetygsfördelning ansågs inte viktigt, efterom syftet med denna studie var att prova bedömningsanvisningen på alla provbetygsnivåer.

De utvalda 109 hela elevproven kopierades fullständigt i två exemplar. Det innebar nästan 1200 uppgifter att ombedöma. Innan kopieringen hade alla ursprungliga lärares ifyllda streck, kommentarer och indikationer på uppgiftsbedömning maskerats. Förberedelserna innebar ett relativt stort arbete, eftersom så många lärare var inblandade och antalet prov var stort. På grund av problem med ofullständigt kopierade häften så blev det slutgiltiga antalet ombedömda hela prov 101.

Resultat

\footnotetext{
${ }^{3}$ Att det blev enbart $9 \mathrm{~F}$ kom sig av att för att fördelning skulle vara jämn mellan pojkar och flickor, och i de inskickade var antalet flickor med betyg F så lågt.
} 


\section{Resultat inom kategorin consensus estimates}

Alla 101 elevproven är således bedömda tre gånger, först av den ursprungliga läraren och därefter två gånger av olika lärare från ombedömargruppen. Bedömningen har resulterat i ett provbetyg, beräknat på precis samma sätt som vid de ursprungliga proven.

Observera att "överenstämmelse" i tabellen nedan innebär att alla tre bedömningarna är helt lika vad avser provbetyg.

Tabell 2. Överensstämmelse mellan Lärargrupp/Bed1/Bed2 vad gäller provbetyg, $n=101$

3 bedömare

6 skalsteg

(provbetyg)

Skillnad $\mathrm{i}$

\begin{tabular}{lllllll} 
steg & 0 & 1 & 2 & 3 & 4 & 5 \\
\cline { 2 - 7 } antal & 49 & 48 & 4 & 0 & 0 & 0
\end{tabular}

För 49 av de 101 proven satte alla tre bedömarna samma provbetyg. I 48 fall avvek ett av de tre föreslagna provbetygen högst ett provbetygssteg. I $46 \%$ av dessa 48 fall gav läraren ensam högst betyg, i 54 \% av fallen var en ombedömare högst eller läraren ensam lägst av de tre. Slutsatsen som kan dras är att det finns mycket svaga indicier i detta material - där bedömarna också är lärare - för att anse att de ursprungliga lärarna genomgående bedömer "för snällt".

Följande påpekande bör göras om "ett stegs skillnad": detta innebär att av tre bedömare så är två ense och en har avvikande åsikt. När man ser tabellen ovan kan man tro att det är 50/50 "chans" att man får t.ex. A eller B. Så är det alltså inte, "majoriteten" är ense, t.ex. B, B, A. Detta är anledningen till att sträv efter att ha minst tre bedömare i denna typ av test. I internationell litteratur är det vanligt med två "ratersMen trots det utökade arbetet, är tre bedömare - raters att föredra. Om man bara har en ombedömare så kan skillnader förstärkas. Ännu bättre ur denna aspekt är fyra. Då skulle t.ex. "ett stegs skillnad” kunna innebära att tre bedömare är ense. Men eftersom det nästlade upplägget innebär relativt många bedömare redan vid två ombedömningar, så har i denna studie antalet bedömningar begränsats till totalt tre. Fördelen med tre är att man ser om en avviker och två är ense, eller om alla tre är helt oense.

I denna studie var det endast i 4 av 101 prov som skillnaden i bedömingen uppgick till 2 provbetygssteg. I ett fall var läraren ensam högst och bedömarna avvek båda med 2 steg, i tre fall var läraren högst, men med ett stegs skillnad mellan bedömarna. Inga skillnader var större än två provbetygssteg. I de senare tre fallen undersöktes bedömningarna på uppgiftsnivå och det visade sig då att det var endast ett poäng ("belägg") av totalt 79 i den lägsta bedömningen som avgjorde att det inte i stället blev ett stegs skillnad.

Spridningen av provbetyg blev: 
Tabell 3 Medelvärde av bedömningar Delprov A+B, Ämnesprov samhällskunskap 2013, sexgradig skala, $F=0, A=5$

\begin{tabular}{lll}
\hline Bedömare & $\begin{array}{l}\text { Medel- } \\
\text { värde }\end{array}$ & $\begin{array}{l}\text { Standard- } \\
\text { avvikelse }\end{array}$ \\
\hline Lärargruppen & 2,85 & 1,56 \\
Bed1 & 2,54 & 1,36 \\
Bed2 & 2,56 & 1,31
\end{tabular}

Skillnaden mellan högsta och lägsta värdet är 0.31 på en sexgradig skala, dvs. knappt en tredjedels provbetygssteg. Standardavvikelsen visar lite olika spridningsmått; lärargruppen sprider sina betyg något mer än bedömargrupperna.

Vid användning av korrelationsmåttet intra class correlation blir ICC $(2,1)$ 0.90 med ett 95\%-igt konfidensintervall mellan 0,85 och 0,93. Detta kan anses som högt. ${ }^{4}$

\section{Resultat inom kategorin consistency estimates}

Consistency översätts i detta sammanhang bäst med överensstämmelse, alltså hur samstämmiga bedömarna är. Olika beräkningsmetoder ger här olika utfall. Om konsekvensen är sådan att bedömare 2 alltid ger +4 poäng i varje uppgift i förhållande till bedömare 1 , så blir Spearmans rho och Pearsons $r=1$. Överensstämmelsen är lika, medan ICC, graden av consensus, blir mindre än 1.

Vid beräkning med Spearmans rho så blir de tre korrelationerna, mellan lärare-ombedömare1, mellan lärare-ombedömare 2, och mellan ombedömare 1 och 2 , respektive $0,92,0,92$ och 0,93 , alltså hög överensstämmelse mellan de tre bedömargrupperna.

Betygssystemet för provbetygen genererar en 6-gradig skala. Korrelationen är känslig för antalet skalstreck. För att testa utfallet utan provbetygets randvillkor, dvs. att man indelar resultatet i olika provbetyg med hjälp av vissa villkor, har också en korrelationsberäkning på den rena "poängsumman” genomförts, dvs. totala antalet belägg som de olika elevhäftena genererat enligt de olika bedömarna. Man kan säga att man i denna jämförelse istället har en betygsskala på 74 steg (högsta antalet erhållna belägg/mätpunkter). Nu ligger alla de tre korrelationerna på 0,96 (Spearmans rho). Införandet av den sexgradiga skalan innebär att korrelationen sjunker, vilket var väntat.

Som jämförelse gjordes beräkningar av $\operatorname{ICC}(2,1)$ på materialet med totalpoäng, vilket resulterade i en korrelation på 0,95.

\footnotetext{
${ }^{4}$ McGraw\&Wong (1996) använder uttrycket agreement istället för consensus. I SPPS (Detta verkar vara det enda ställe där denna förkortning används. Det kanske är allom bekant vad den står för? Om inte, bör den nog förklaras.) återfinns detta uttryck. ICC delas enligt Shrout och Fleish (1996) in i tre kategorier med underavdelning, sex olika utfall. (Svårt att förstå vad som menas med föregående mening.)Vår studie kunde vara en Case $(1,1)$, men Case $(2,1)$ är SPSS och i Excel med tillägget "Real Statistics Function” det som mäter ICC(Agreement(Friedman 2005; Brown 2005)
} 


\section{De enbart öppna uppgifterna.}

Fokus i denna studie har legat på utfallet i ett slutligt provbetyg. I beräkning på hela provbetyget innehåller flera av mätpunkterna uppgifter med strukturerade svarsalternativ. Om utfallet från rent strukturerade svarsalternativ (t.ex. multiple-choice) och semi-öppna (blandade uppgifter med strukturerat + kortsvar) rensas bort, kvarstår de enbart öppna uppgifterna. Då har det inte varit möjligt att få ut något provbetyg ur materialet. I denna jämförelse med de enbart öppna uppgifterna har enbart ombedömarna tagits med då det i detta läge varit svårt att urskilja de enskilda lärarnas poäng på enskilda uppgifter.

Spearmans rho för detta material blir 0,92. Detta skall alltså jämföras med Spearmans rho ovan, när skalstegen (provbetyget) togs bort, 0,96. Hela provet innehöll ju ett antal strukturerade uppgifter. Men även för de enbart öppna uppgifterna är resultatet gott.

Fokus för denna studie var dock att se på samstämmighet på provbetygsnivå. En fördjupad undersökning av de enbart öppna uppgifterna kommer att göras i den kommande studien 2019.

\section{Sammanfattning och diskussion}

Kursplanen i samhällskunskap enligt Lgr11 betonar elevernas förmåga att resonera och beskriva samband. För att visa dessa förmågor så måste en del av uppgifterna i ett ämnesprov i samhällskunskap vara öppna. Att på ett adekvat och tydligt sätt ge instruktioner om hur dessa ofta komplexa svar skall bedömas blir en mycket viktig del i likvärdighetskravet. I Sverige är diskussionen stor huruvida lärarna på fältet, som är bedömarna av nationella prov, bör sambedöma mer eller istället borde få mer bedömarträning (Gustavsson et al, 2014).

Huvudsyftet med denna studie var att pröva om det nationella provet $\mathrm{i}$ samhällskunskap med många relativt helt öppna frågor, kan anses vara stabilt vad det gäller interbedömarreliabilitet. I denna studie förefaller överenstämmelsen ha varit mycket god. Måtten på consistency estimates är höga trots inslaget av helt öppna frågor. Vad det gäller kategorin consensus estimates visar den på god överenstämmelse. Det blir intressant att följa upp hur långt man kan utveckla bedömningsanvisningarna inom denna kategori. I prov med öppna frågor med många möjligheter för eleverna att svara är det svårt att nå fullständig överensstämmelse mellan bedömare. I det fortsatta utvecklingsarbetet gäller det att få fram tydliga bedömningsanvisningar som ändå ger eleven de möjligheter att svara som enligt kursplanen ska bedömas.

I de tre bedömargrupperna, lärarna och de två ombedömargrupperna, fanns det med stor säkerhet intra-bedömar-effekter, som påverkade resultatet. Det innebär att korrelationerna torde visa ett sämstaläge vad gäller interbedömarreliabilitet, som är det rapporten fokuserar på. Förhoppningsvis innebär 
resultatet en positiv utvärdering av bedömningsanvisningarnas säkerhet som bedömningsunderlag.

I den digitala enkätundersökning, som lärarna gjorde efter att ha genomfört bedömning av provet 2013, ansåg c:a 84 \% att bedömningsanvisningarna gav bra eller tillräckligt stöd i bedömningen, och på frågan om bedömningsanvisningarna var tillräckligt tydliga svarade c:a $83 \%$ bra eller absolut (n=421) (Göteborgs universitet, 2013).

\section{Utvecklingsmöjligheter}

Denna studie redovisar resultatet av ett material som prövats för första gången. Utvecklingsmöjligheterna är många.

Fokus i denna studie har varit jämförelse mellan resultaten på hela provet, uttolkat som ett provbetyg. Anledningen till det var att det är denna jämförelse som oftast diskuteras. Men även även vid jämförelser mellan utfallet i poäng för de rent öppna uppgifterna är korrelationen god.

Proven idag (2018) har högre andel öppna uppgifter, 50 \%, istället för drygt $30 \%$ i 2013 års prov, som denna studie behandlade. Antalet uppgifter är dock lägre idag (24 istället för 30) och antalet öppna uppgifter, de som skall bedömas, är 12 istället för 11. Detta kan innebära sämre reliabilitet, förhoppningsvis också att utvecklingen av provet och bedömningsanvisningarna gjort att samma goda värden på vår interbedömarrelibilitet kan behållas.

\section{Korrelationsmått}

Den statistiska vetenskapliga litteraturen bjuder på ett rikt utbud av korrelationsmått. För jämförbarhet denna studie valt att ha ett upplägg liknande det som Skolverket tidigare tidigare använde. Vad gäller consensus estimates återstår en del utvecklingsarbete med att jämföra och arbeta fram ett mått och en modell som passar vår typ av ämnesprov. I denna studie har använts Intra Class Coefficient som förslag på lämpligt mått men även det bör diskuteras och användas på fler studier.

\section{Bedömningar}

Skolverket (2009) föreslår flera utvecklingsområden för interbedömarstudier, t.ex. att se på skillnader i bedömning pojkar/flickor och skillnad i bedömning mellan skolor.

Väl genomförda interbedömarreliabilitetsstudier tar tid och är med denna typ av nästlade studier, som förutsätter deltagande av många lärare från olika skolor, en resurskrävande verksamhet. Men med tanke på den mängd data sådana studier tillför i utvecklingsarbetet med de nationella proven inom samhällskunskap och andra ämnen, ter det sig som en oundgänglig verksamhet. 
”I alla situationer där bedömare i någon utsträckning är involverade är det viktigt att bedömaröverensstämmelsen är så hög som möjligt i och med att bedömaröverensstämmelsen har betydelse för de bedömda elevresultatens validitet.”5

\section{Kommande studier}

Studien kommer att upprepas med provet som genomförts i april 2018.

\section{Om författaren}

Arne Löfstedt er Projektledare Nationella prov och bedömningsstöd samhällskunskap åk 6 och åk 9 ved Göteborgs universitet. Hans forskningsinteresser omfatter blant annet item response theory, interbedömarstudier och forskning kring ämnet samhällskunnskap.

Institutionsanknytning: Institutionen för pedagogik och specialpedagogik, Göteborgs universitet, Box 300, 40530 Göteborg, Sverige.

E-post: arne.lofstedt@gu.se

\section{Referanser}

Bartko, J. J. (1976). On various intraclass correlation reliability coefficients. Psychological Bulletin, 83(5), 762-765. doi:10.1037/0033-2909.83.5.762

Brown, G. (2005, 17-20 okt.). The Family of Reliability Coefficients. Paper presenterad på BIRN 2005, La Jolla. Hämtad april 2014 från http:/www.na-mic.org/Wiki/images/7/79/Reliability_family_finiOct2005.ppt

Erickson, G. (2009). Nationella prov i engelska - en studie av bedömarsamstämmighet. Göteborgs universitet. Hämtad 2018-11-01 från https://www.nafs.gu.se/digitalAssets/1319/1319572_bed.np-eng-g.erickson-2009.pdf

Friedman, L. (2005, 17-20 okt.). Measuring Reliability: The Intraclass Correlation Coefficient. Paper presenterad på BIRN 2005. Hämtad april 2014 från www.na-mic.org/Wiki/index.php/File:ICC_LectureFriedman2005.ppt

Friedman, L., Stern, H., Brown, G. G., Mathalon, D. H., Turner, J., Glover, G. H., . . Potkin, S. G. (2008). Test-retest and between-site reliability in a multicenter fMRI study. Human Brain Mapping 29(8), 958-972. doi:10.1002/hbm.20440

Gustavsson, J-E., Cliffordsson, C., \& Erickson, G., (2014). Likvärdig kunskapsbedömning i och av den svenska skolan - problem och möjligheter. (SNS-rapport). Stockholm: SNS Förlag.

Gwet, K. (2002a). Inter-Rater Reliability: Dependency on Trait Prevalence and Marginal Homogeneity. Series: Statistical Methods For Inter-Rater Reliability Assessment, No. 2, May 2002. Hämtad 2018-08-07 från http://www.agreestat.com/research_papers/inter_rater_reliability_dependency.pdf

Gwet, K. (2002b). Kappa Statistic is not Satisfactory for Assessing the Extent of Agreement Between Raters. Series: Statistical Methods For Inter-Rater Reliability Assessment, No. 1,

\footnotetext{
${ }^{5}$ Stemler 2004 citerad i Skolverket (2009).
} 
April 2002. Hämtad från

http://agreestat.com/research_papers/kappa_statistic_is_not_satisfactory.pdf

Göeborgs universitet. (2013). Ämnesproven i grundskolans årskurs 9 och specialskolans årskurs 10, Samhällskunskap Årskurs 9 Vårterminen 2013.

Hämtad 2018-05-22 från https://www.npsoportal.se/files/2014/12/rapport_samhallskunskap9.pdf

Landis, J., \& Koch, G. (1977). The Measurement of Observer Agreement for Categorical Data. Biometrics, 33(1), 159-174. doi:10.2307/2529310

Mcgraw, K. \& Wong, S. P. (1996). Forming Inferences About Some Intraclass Correlation Coefficients. Psychological Methods. 1. 30-46. doi: 10.1037/1082-989X.1.1.30.

PRIM-gruppen, Stockholm. (2009) Bedömaröverensstämmelse vid bedömning av ämnesprovet i matematik för årskurs 9. Hämtad 2018-11-01 från

https://www.su.se/polopoly_fs/1.399781.1536237181!/menu/standard/file/Matematik\%20ISB R\%202009.pdf

Shrout, P. E. \& Fleiss, J. L. (1979). Intraclass Correlations: Uses in Assessing Rater Reliability. Psychological Bulletin 1979:86:2, 420-428. doi/10.1037/0033-2909.86.2.420

Sjöberg, R. (2015, 4-6 mars). The black-boxed interrater reliability: On the overlooked distinction between absolute and relative rater variability in the criterion-referenced policy era. Paper presenterad på NERA 2015. Hämtad januari 2018 från https://www.gu.se/forskning/publikation/?publicationId=213501

Skolverket. (2009). Bedömaröverensstämmelse vid bedömning av nationella prov. Dnr 2008:286. Hämtad 2018-11-01 från https://www.skolverket.se/sitevision/proxy/publikationer/svid12_5dfee44715d35a5cdfa28 99/55935574/wtpub/ws/skolbok/wpubext/bilaga/Blob/pdf139.pdf?k=139

Skolverket. (2017). Skolverkets systemramverk för nationella prov. Hämtad 2018-11-01 från https://www.skolverket.se/publikationer?id=3890

Stemler, S. E. (2004). A comparison of consensus, consistency, and measurement approaches to estimating interrater reliability. Practical Assessment, Research \& Evaluation, 9. Hämtad 2013-12-03 från http://PAREonline.net/getvn.asp?v=9\&n=4.

Stemler, S. E. \& Tsai, J. (2008). Best Practices in Interrater Reliability Three Common Approaches. I Osborne, J. (Ed.), Best practices in quantitative methods (s. 29-50). Thousand Oaks, CA: SAGE Publications, Inc

Uebersax, J. (1987). Diversity of Decision-Making Models and the Measurement of Interrater Agreement. Psychological Bulletin 87(1), 140-146. doi:10.1037/0033-2909.101.1.140

Uebersax, J. (2015) The tetrachoric and polychoric correlation coefficients. Hämtad 2018-0115 från http://john-uebersax.com/stat/tetra.htm.

Östlund-Stjärnegårdh, E. (2009). Bedömaröverensstämmelse - ämnet svenska. Uppsala: Uppsala universitet 
Bilaga 1 Kunskapskraven i samhällskunskap, åk 9, Lgr11

(Progressionsuttrycken för de olika nivåerna E, C och A (t.ex enkla/utvecklade/välutvecklade resonemang) är ersatta med *. Övrig text är alltså lika mellan betygsstegen)

\section{Delkunskapskrav 1:}

Eleven har * kunskaper om olika samhällsstrukturer. Eleven visar det genom att undersöka hur sociala, mediala, rättsliga, ekonomiska och politiska strukturer i samhället är uppbyggda och fungerar och beskriver då * samband inom och mellan olika samhällsstrukturer. I beskrivningarna kan eleven använda begrepp och modeller på ett * fungerande sätt.

\section{Delkunskapskrav 2:}

Eleven kan föra * resonemang om hur individer och samhällen påverkas av och påverkar varandra och beskriver då * samband mellan olika faktorer som har betydelse för individers möjligheter att påverka sin egen och andras livssituation.

\section{Delkunskapskrav 3:}

Eleven kan undersöka elevnära samhällsfrågor ur olika perspektiv, och beskriver då * samband med * underbyggda resonemang. Eleven värderar och uttrycker olika ståndpunkter i några samhällsfrågor med * resonemang och * underbyggda argument och kan då i * utsträckning växla mellan olika perspektiv.

\section{Delkunskapskrav 4:}

Eleven redogör för de mänskliga rättigheternas innebörd och betydelse och ger exempel på hur de kränks och främjas i olika delar av världen. Dessutom kan eleven redogöra för de nationella minoriteterna och deras särställning och rättigheter.

\section{Delkunskapskrav 5:}

Eleven har * kunskaper om demokratiska värden och processer och visar det genom att föra * resonemang om demokratiska rättigheter och skyldigheter, samt och för- och nackdelar med olika former för gemensamt beslutsfattande.

\section{Delkunskapskrav 6:}

Eleven kan söka information om samhället och använder då olika källor på ett * fungerande sätt och för * underbyggda resonemang om informationens och källornas trovärdighet och relevans.

I ämnesprovet 2013 prövades delkunskapskraven 1, 3 och 5. 